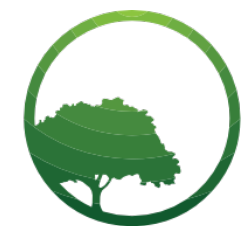

Business \& Social Science IJRBS

\section{Research in Business and Social Science}

IJRBS Vol 6 No 3, ISSN: 2147-4478

Contents available at www.ssbfnet.com/ojs

http://dx.doi.org/10.20525/ijrbs.v6i3.758

\title{
Environmental Determinants of Choice of Sustainability Strategies Adopted by Group Ranches in Samburu County, Kenya
}

\section{Eustace Njagi Kithumbu}

Corresponding Author: Department of Business and Entrepreneurship, Karatina University, Nairobi, Keny,:+2540715316464.

\section{Julius M. Huho}

Prof., Department of Arts and Social Sciences, Garissa University, Nairobi, Kenya

\section{Humphrey R. Omondi}

Dr., Department of Business and Entrepreneurship, Karatina University, Narobi, Kenya

\begin{abstract}
The group ranch system is one of the best land ownership and livestock production strategies in the dry lands of the world where the potential for rain-fed agriculture is limited. Its sustainability relies greately on choice of sustainability strategies adopted by group ranches. Numerous studies on the establishment of group ranches, their dissolution and coping strategies have been conducted but with less focus on the sustainability of the group ranches. This study attempts to fill the gap. It is against this background that this study investigated environmental characteristics influencing choice of sustainability strategies adopted by group ranches in Samburu County, Kenya. The investigation adopted a descriptive survey research design employing use of Questionnaires, Key Informant Interviews, Focus Group Discussions and observation as primary data collection methods. The target population for the study was the 16,611 registered members in 38 group ranches spread out in the County. The study sampled 12 group ranches with approximately 5,643 members from which 374 respondents were systematically sampled. Purposive sampling was used to select Key Informants and the participants in the Focus Group Discussions. The study employed Multi-linear Regression to analyse environmental characteristics determining choice of sustainability strategies. The Analysis of Variance (ANOVA) was used to test the hypothesis and p-value of 0.00 was obtained, indicating that environmental characteristics (rainfall patterns, droughts, temperatures, diseases and floods) significantly influenced choice of sustainability strategies adopted by group ranches in the County. Overall, rainfall patterns were the predominating environmental characteristic with a regression coefficient of 0.317 while diseases had the least influence on choice of sustainability strategies adopted by group ranches in Samburu County, with a regression coefficient of 0.029. The study recommended integration of environmental characteristics in formulating policies for sustainability of group ranches.
\end{abstract}

Key words: Environmental Determinants, Choice of Sustainability Strategies, Adoption, Group Ranches, Samburu County 


\section{Introduction}

Ranching is the practice of raising livestock on large tracts of land and occurs mostly in the climatically marginalized rangelands where the potential for rain-fed agriculture is limited due to environmental challenges (Huho, Ngaira \& Ogindo, 2010; Hatfield \& Davies, 2006). It is the main land-use in the rangeland ecosystems the world over with considerable cultural, economic and ecological importance (Hussey, 2010). In America, the rangelands comprise about 40 per cent of the landmass. In Australia, they occupy about 70 per cent of the continent, much of which is used for livestock production (Brown \& Gilfoyle, 2009). In Africa, the rangelands occupy 43 per cent of the continent's land mass; 70 per cent of Eastern Africa and more than 80 per cent of the Kenya landmass is considered to be arid and semi-arid, suitable for ranching (Hoffman \& Vogel, 2008).

Ranching is an important livestock production system that is practised by over 200 million people worldwide (United Nations Environment Programme [UNEP], 2015). In Kenya, it remains the best sustainable production system in the semi-arid and arid lands (ASALs) particularly in Mandera, Wajir, Garissa, Tana River, Marsabit, Isiolo, Turkana, West Pokot, Baringo, Kajiado, Narok, Laikipia and Samburu Counties (Kipaioni, 2013; Huho, 2011). Sustained ranching in the rangelands is therefore critical in uplifting the living standards of the ranching communities as well as generating rapid economic growth (Ntiati, 2002).

Arising from global challenges of water scarcity, increased population growth rates, climate change and increase in demand for livestock products, greater importance is being attached to land ownership in the rangelands (United States Agency for International Development [USAID], 2011). Land is a base for food production and income generation, serves as collateral for credit and is a means of holding savings for the future. It is also a social asset that is crucial for cultural identity, social status, political power and participation in decision making (National Land Commission Strategic Plan, 2013-2018). Therefore, land ownership plays a significant role in the economic, social, cultural and political development of many economies the world over(Wayumba, 2013).It is also challenging for people living in the rangelands to make long-term and sustainable improvements on the land whose security of tenure has not been recognized, protected and registered Thus ownership and sustainable utilization of land in the ASALs is important for the broader economic growth and poverty reduction (Constitution of Kenya, 2010: Kibugi, 2008).

In the pre-colonial times, land in the rangelands of Africa, was abundant with ranching being the main economic activity (USAID, 2011). Land was held as a trans- generational asset whose management was at different levels of the social organizational structure (Karodia \& Soni, 2014) with its access and control depending on an individual's place in the social order of the community. However, land tenure and its management have undergone an evolutionary transformation (Lesorogol, 2008) with individualization and privatization of land becoming increasingly common in the rangelands (Mwangi, 2007). As Borwein (2013) observed group ranches were established as a form of collective land ownership to privatize communal land in the rangelands.

Before colonization, land in Kenya belonged to the whole community and its management, access, and control depended on the customs and practices of the particular communities (Wachira, 2008). Communities, particularly the pastoralists, such as the Samburu, Maasai and the Borana preferred communal land ownership where every person in the community had rights of access to the land (Mwakima, 2013).

After independence, the drive to privatize land in Kenya made the post-colonial government establish group ranches in the Arid and Semi-Arid parts of the Country which went hand-in-hand with the Kenya Livestock Development Project (Baumann, 2011; Moiko, 2011). The government had realized that the ecology of the ASALs favoured communal land ownership in form of group ranches instead of individual land ownership (Mwangi, 2007). As observed by Mule (2010) communal land ownership in the ASALs was more appropriate as it allowed migration of livestock within group ranches and to the neighbours for pasturage that was a critical coping strategy against unreliable rainfall patterns, extreme temperatures, droughts and diseases. 
The group ranches were the principal means through which community land previously held by the defunct county councils was adjudicated and registered to the members (Odari, 2010; Lesorogol, 2008). They contributed about 10 per cent of Kenya's Gross Domestic product (GDP) and were a critical source of economic activity in the dry areas of Kenya where rain-fed agriculture was hardly practised (Fratkin, 2008). Kenya's livestock production system accounts for 24 per cent of the total agricultural output and is worth about US $\$ 800$ million per year (AU-IBAR in IIED and SOS Sahel, 2010).

In Samburu County, group ranches were the main sources of livelihood as they provided for about 90 per cent of employment and more than 95 per cent of family incomes (Food and Agriculture Organization [FAO], 2005). Besides being the main source of income, group ranching also provided livestock that was used for cultural and religious roles like dowry payment, symbol of prosperity and prestige (Noor, Guliye, Tariq \& Bebe, 2013).

However, by the 1980s, most of the group ranches established in the late 1960s and early 1970s had dissolved and sub-divided into very small land holdings that were ecologically and economically unviable for ranching (Mule, 2010). This coupled with mismanagement practices, left members staring at what Masharen (2015) referred to as economic ruin, thus raising questions about the future of group ranches in Kenya (Gaitho, 2014; Veit, 2011). Nevertheless, the group ranches that resisted the temptation to dissolve adopted strategies such as income generating activities, partnerships, investments in the community wellbeing and leasing of land to private developers for sustainability (Kipainoi, 2013).

In the County of Samburu, Kenya, land demarcation/surveying started in the early 1970s (Ministry of Lands and Physical Planning [MoLPP], 2016). Initially, the communities living in the County were opposed to the group ranch concept but later on the desire to own land communally grew and forty-two group ranches were established (National Land Commission [NLC], 2014 ; Lesogorol,2008). However, due to climate change, increased population growth rate, loss of pastureland, insecurity and mismanagement, group ranches in Samburu County were under pressure to subdivide, ushering in a scenario that would not support ranching (United Nations Development Programme [UNDP], 2015). Thus the biggest challenge facing group ranches was now to strike a balance between satisfying livelihood needs of the members and sustainable use of resources found within the ranches (Mwakima, 2013).

Therefore, the study expects to examine environmental determinants of choice of sustaianiblity strategies adopted by group ranches in Samburu County, Kenya.

\section{Literature Review}

This study was guided by the Tragedy of the Commons Theory which states that any land that is communally held will be unavoidably overgrazed. The theory describes a situation where there is a conflict over resources between individual interests and the common good (Lengoiboni, 2011) and occurs when individuals ignore the well-being of the group in the pursuit of personal gains (Borwein, 2013; Mwangi, 2007).The Tragedy of the Commons Theory was applied to explain environmental characteristics that influenced choice of sustainability strategies adopted by group ranches in Samburu County. The theory was used because most of the group ranches were established in environments with unpredictable and unreliable climatic conditions with limited pastureland.

One of the most important management functions in an organization such as a group ranch is choice of a strategy that must be fully understood by the management before execution (Nooraie, 2011). Although most of the environmental influences on choice of strategies are generally understood to be task-related and competition-borne, the physical environment or climatic conditions play a significant role in influencing strategies adopted by organizations such as group ranches (Deressa, et al, 2010). For instance, the growing global environmental change and increased climate variability are the physical environmental factors that influence choice of strategies adopted by organizations to reduce the risks associated with such variability (Calder \& Ziervogel, 2003). Rainfall pattern has been identified as the single most important factor influencing land use practices, whether crop production, livestock or wildlife conservation (Ntiati, 2002). Calder et al (2003) observed that rain-fed agricultural strategies were influenced by variability of rainfall that impacted negatively on the livelihood security of the farmers. They further observed that 
unreliable rainfall patterns had an impact on the livestock production system and affected the rangeland conditions with reduced pasturage. It was observed that low rainfall influences the performance of the individual animal while very heavy rainfall predisposes the animals to diseases and parasites, leading to death.

The International Livestock Research Institute (2010) reported that drought affected ranching in the rangelands of Kenya that cover $80 \%$ of the landmass with annual rainfall varying from 200 to $500 \mathrm{~mm}$ (Kandji et al 2006). Due to droughts and other unfavourable environmental factors, the farmers developed both short-term and long-term strategies to cope with effects of environmental challenges (Huho, Ngaira \& Ogindo, 2010; International Strategy for Disaster Reduction, 2005).

The short-term drought coping strategies aimed at minimizing loss of livestock and their choices differed from one drought event to the other depending on the severity of the drought. These strategies included: grazing livestock early in the morning; establishment of feed reserves; formation of alliances with neighbours; migration and digging of shallow wells on the river beds. The long-term drought coping strategies aimed at cushioning the farmers against livestock losses during drought periods. They included: keeping livestock of mixed species; keeping of indigenous livestock breeds; keeping of female dominated herds; and increasing of herd sizes during inter-drought periods (Kipaioni, 2013; Huho, Ngaira \& Ogindo, 2010).

Migration involved moving livestock from one grazing area to another in search of pasture and water. In Kajiado and Narok Counties, for instance, ranchers moved with their livestock for more than 40 Kilometres while others dispersed (spreading one's animals to several localities to counteract local risks of theft and diseases) their livestock among friends and relatives in different ecological zones to avoid loss of entire stock (Huho, 2011). As a coping strategy, livestock mobility ensured that animals got fresh pastures and minerals; accessed water supplies; avoided overgrazing resources, human competitors and diseasecarrying insects(Kipainoi,2013;). Literature revealed that rich households applied the herd mobility strategy more than the poor ones by moving a larger proportion of their herds while the poor households applied the strategy of keeping drought resistant animals more than rich ones by having a higher proportion of goats and sheep than cattle (Mariara, 2004).

The literature review also revealed that floods impact negatively on communities with far reaching social and economic consequences. The immediate impacts of flooding include loss of human life, damage to property, loss of livestock, and deterioration of health conditions owing to waterborne diseases. Floods cause damage and disrupt communication links and infrastructure such as power plants, roads and bridges leading to a standstill of economic activities.Furthermore, people are forced to leave their homes, disrupting their normal life (United Nations Development Programme, 2005).

The aforementioned studies dealt more on coping strategies than on sustainability strategies.Some environmental factors like floods and temperatures were mentioned to have an influence on the livestock production system but there was little indication of how the factors influenced choice of sustainability strategies.Hence, there was need to determine environmental characteristics influencing choice of sustainability strategies adopted by organizations such as group ranches.

\section{Research and Methodology \\ Questionnaire Development}

The Questionnaires were the main tools used to collect the necessary information from the sampled respondents. They contained both closed and open-ended questions and were administered by the researchers and the research assistants. Where the respondents requested to be given more time to fill, the questionnaires would be dropped and picked later.The questionnaires were developed in English but they were translated into Kiswahili or Samburu languages whenever the researchers and their assistants came across respondents who never understood English language.

The questionnaires consisted of three major sections ( $A, B$ and $C$ ). Section $A$ asked five questions regarding demographic data on the respondents. Section $B$ asked questions on the group ranch activities while Section $C$ had questions on environmental characteristics perceived by the respondents to have 
influence on choice of sustainability strategies adopted by group ranches in the study area. In addition, the respondents were asked questions indicating the extent to which each independent variable influenced the dependent variable (choice of sustainability strategies). The questions in Section C used five-point Likerttype items, anchored by $1=$ Not at all, 2=Low extent, 3=Moderate extent, $4=$ Great extent and $5=$ Very great extent.

Further, a conceptual framework was developed to illustrate the relationship between the independent variables and the dependent variable (figure 1).

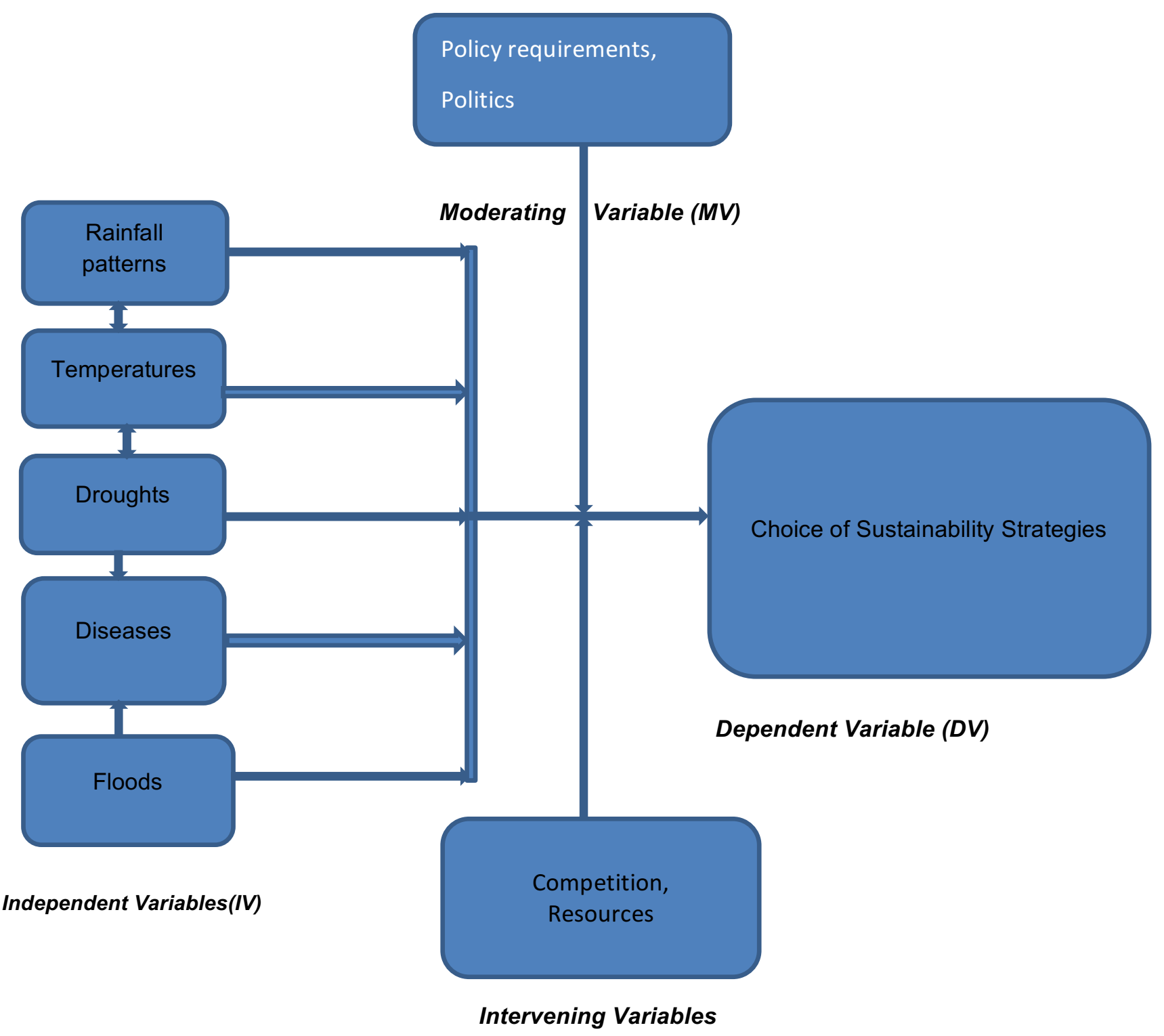

Figure 1: Conceptual framework

Figure 1 is a diagrammatic representation of the relationship between the independent variables (rainfall patterns, droughts, diseases and floods) and the dependent variable (choice of sustainability strategies). The diagram also shows the moderating variables (policy requirements and politics) and intervening variables (resources and competition) that directly or indirectly affected the degree of the relationship between the independent variables and the dependent variable. A moderating variable is a variable that changes (increases or decreases) the otherwise established influence of the independent variable upon the 
dependent variable while the intervening variable is used to explain causal links between variables (Kothari, 2004).

\section{Sampling and Data Collection}

Sampling involved construction of a sample frame of 16,611 items indicating the registered members of all the group ranches in Samburu County. There were approximately 16,611 registered members of group ranches in Samburu County.We compared all the registers kept by the Registrar of Group Representatives in Nairobi with those kept by the Assistant Registrar, Samburu and Chairmen of the respective group ranches in the county to make sure that we were dealing with the correct registers.

Sampling of the population in the study was necessary because a target population of 16,611 registered members was too large for a complete enumeration. Furthermore, sampling would save time and money, allow more time to be spent on training research assistants, testing and checking the instruments (Ng'ang'a, et al, 2009). We sampled 30 per cent of the 38 group ranches operating in Samburu County to give a sample size of 12 group ranches as recommended by Mugenda and Mugenda (2003), a sample of between 10 per cent and 30 per cent of the accessible population for a descriptive research design is acceptable.The sampled 12 group ranches had approximately 5,643 registered members from which the study sample size of 374 respondents was drawn and the following formula was adopted to determine the sample size:

$$
\mathrm{n}=\frac{\mathrm{N}}{1+\mathrm{N}(\mathrm{e})^{2}} \text {, Where } \mathrm{n}=\text { desired sample size, } \mathrm{N}=\text { Target population, } \mathrm{E}=\text { error term and } 1 \text { is a constant. }
$$

Therefore $\mathrm{n}=\frac{5643}{1+5643(0.05)^{2}}=\frac{5643}{1+5643 \times 0.0025}=5643$

$\mathrm{n}=\underline{5643}=373.523=\mathbf{3 7 4}$ (group ranch members)

15.1075

The main sampling procedures used in the study were systematic and purposive sampling. Systematic sampling involves selecting every $\mathrm{n}^{\text {th }}$ item on the sample frame ( $\mathrm{Ng}^{\prime}$ 'ang'a, et al, 2009; Kothari, 2004) and the strategy was used to select 12 group ranches and 374 respondents from the selected 12 out of 38 group ranches in the study area.

Purposive sampling strategy was used to select respondents considered to have common things like experience, intuition and expertise in the subject being studied ( $\mathrm{Ng}^{\prime}$ ang'a, et al, 2009). The strategy is also used in the selection of a group of subjects from a larger group for study based on the judgment of the researcher as to which subjects best fit the criteria of the study (Huho, 2011).The strategy was used to select Key Informants who included Director of Land Adjudication and Settlement, the Registrar of group representatives, officers from Samburu County Government and other experts in the land sector. The Key Informants gave information on the environmental characteristics that influenced choice of sustainability strategies adopted by group ranches. Purposive sampling was also used to select participants in the Focus Group Discussions who gave views on the environmental characteristics influencing choice of sustainability strategies adopted by group ranches in Samburu County.

\section{Analysis}

The data was analysed using SPSS version 21.0 and complemented by Microsoft Excel.The relationship between independent variables (droughts, rainfall patterns, temperatures, diseases, floods) and dependent variable (choice of sustainability strategies)was described by use of the following regression model: $Y=\beta_{0}+\beta_{1} X_{1}+\beta_{2} X_{2}+\beta_{3} X_{3}+\beta_{4} X_{4}+\beta_{5} X_{5}+e$. Where, $Y=$ Choice of sustainability strategies; $X X_{1}=$ Droughts; $X_{2}=$ Rainfall patterns; $X 3=$ Temperatures; $X 4=$ Diseases; and $X 5=$ Floods (Table1).Analysis of Variance 
(ANOVA) was used to test the hypothesis which stated that environmental characteristics had no significant influence on choice of sustainability strategies adopted by group ranches in Samburu County, Kenya.

\section{Findings}

The results indicated that rainfall patterns had the greatest influence on choice of sustainability strategies with a regression coefficient of 0.317 . It was closely followed by droughts, 0.225 ; temperatures, 0.200 ; floods, 0.029 and diseases, 0.196 , in that order (Table 1).

Table 1: Regression Coefficients for environmental characteristics

\begin{tabular}{|c|c|c|c|c|c|c|}
\hline & \multirow[t]{2}{*}{ Model } & \multicolumn{2}{|c|}{$\begin{array}{r}\text { Unstandardized } \\
\text { Coefficients }\end{array}$} & \multirow{2}{*}{\begin{tabular}{|r|}
$\begin{array}{r}\text { Standardized } \\
\text { Coefficients }\end{array}$ \\
Beta \\
\end{tabular}} & \multirow[t]{2}{*}{$\mathrm{t}$} & \multirow[t]{2}{*}{ Sig. } \\
\hline & & $B$ & Std. Error & & & \\
\hline \multirow{6}{*}{1} & (Constant) & 0.135 & 0.024 & & -5.601 & 0.000 \\
\hline & Droughts & 0.225 & 0.006 & 0.189 & 39.908 & 0.000 \\
\hline & Rainfall patterns & 0.317 & 0.005 & 0.279 & 59.384 & 0.000 \\
\hline & Temperatures & 0.200 & 0.001 & 0.851 & 195.601 & 0.000 \\
\hline & Diseases & 0.029 & 0.007 & 0.019 & 4.093 & 0.000 \\
\hline & Floods & 0.196 & 0.007 & 0.126 & 26.595 & 0.000 \\
\hline
\end{tabular}

a. Dependent Variable: Choice of Sustainability Strategies

b. Independent Variables: Droughts, rainfall patterns, temperatures, diseases and floods

\section{Source: Field data, 2016}

The model in Table 1 indicates that when environmental characteristics (rainfall patterns, temperatures, droughts, floods and diseases) were at zero, choice of sustainability strategies was at 0.135 . This means that when other factors were held constant, a unit change in droughts resulted in a 0.225 unit change in choice of sustainability strategies like livestock mobility. For example, the study established that during droughts, the ranchers were forced to drive their livestock to areas with pasturage and water. Similarly, holding floods, diseases and droughts constant, a unit change in rainfall patterns resulted in a 0.317 unit change in the choice of sustainability strategies like conservation. For example, a unit change in rainfall patterns resulted in a 0.317 unit change in establishment of a conservancy to conserve wildlife and to protect group ranches from intruders. The model further indicates that holding other factors constant, a unit change in temperatures led to a 0.200 unit change in choice of sustainability strategies. For example, herders constructed shelters to protect their livestock, especially kids, from the effects of high temperatures. Finally, the study established that a unit change in diseases resulted in a 0.029 unit change in choice of strategies like veterinary services while holding other characteristics, constant, a unit change in floods led to a 0.196 unit change in the choice of sustainability strategies such as keeping off livestock from the flood prone sections of the group ranch.

The Analysis of variance (ANOVA) was used to test the null hypothesis which stated that environmental characteristics had no significant influence on choice of sustainability strategies adopted by group ranches in Samburu County, Kenya (Table 2).

Table 2: Analysis of Variance (ANOVA)

\begin{tabular}{|rl|r|r|c|c|c|}
\hline \multicolumn{1}{|l|}{ Model } & \multicolumn{1}{c|}{$\begin{array}{c}\text { Sum of } \\
\text { Squares }\end{array}$} & df & Mean Square & $\mathrm{F}$ & Sig. \\
\hline \multirow{2}{*}{1} & Regression & 428.210 & 5 & 85.642 & 10881.463 & $0.000^{b}$ \\
& Residual & 2.707 & 344 & 0.008 & & \\
& Total & 430.917 & 349 & & & \\
\hline
\end{tabular}

Peer-reviewed Academic Journal published by SSBFNET with respect to copyright holders. 
Dependent Variable: Choice of Sustainability Strategies

Predictors: (Constant), Diseases, Temperatures, Droughts, Rainfall patterns and floods

The study established a significance value of $p=0.000$ which was less than 0.05 . The null hypothesis was therefore rejected and the alternative hypothesis, which stated that environmental characteristics significantly influenced choice of sustainability strategies adopted by group ranches in Samburu County, Kenya, was accepted.

\section{Sustainability strategies}

A growing trend toward dissolution of group ranches in Kenya has been established. However, in Samburu County most of the group ranches have remained un-dissolved to date despite the environmental challenges facing them. Analysis of the sustainability strategies that have led to holding together of the group ranches in the county established that there existed a strong relationship between group ranches and environment characteristics. The findings revealed that the survival of group ranches dependent on choice of sustainability strategies which were in turn influenced by environment conditions.

Samburu County is characterized by harsh environmental conditions that lead to loss of livelihoods. The group ranches adopted strategies aimed at reducing livestock mortality.Due to unreliable and unpredictable rainfall patterns, periodic droughts and high temperatures in Samburu County, group ranches chose and adopted strategies such as stock mobility, livestock maximization and diversification, herd dispersion, and reservation for rich-patch vegetation. These strategies reduced the risks of livestock mortality by increasing livestock resilience to adverse environmental conditions. Constant livelihood source had a direct bearing on the sustainability of group ranches. The survival and reduction of livestock losses held the fabrics of group ranches together lowering the rates of group ranch dissolution.

The term sustainability strategies in this study is used to refer to the practices adopted by group ranches to hold together (without dissolving and sub-dividing) for the present and future generations. With regards to environmental characteristics, the survival of group ranches dependent on the following adopted strategies:

\section{Migration}

During droughts, the ranchers were forced to drive their livestock to areas with pasturage and water especially in the highlands of Mathews Mountains in Wamba. In addition, livestock were let to roam over the extensive areas within and outside the County in search of pasture and water. Migration patterns within the County included the following: from Girgir group ranch to Losesia group ranch; from Samburu East to Samburu Central, that was Lodogokwe, Kirimun, Kanampiu; Baragoi to Marti; Masikita to Suyani; Nachola to Lomeroko, Turkana border; Tuum to Mt. Nyiro in Samburu North;Wamba to Laresoro; and Lorroki lowland towards Kirisia hills in Samburu Central. Migration patterns outside Samburu County included: from Samburu East Sub County to Laikipia North Sub-County; Merille area in Marsabit County; and Merti area in Isiolo County. It was established that livestock migration was often preceded by scouts who moved ahead of the livestock to assess the resource availability and quality, and to collect information on the grazing potentials of the area to which the livestock were moving. This strategy ensured that livestock got adequate pastures, accessed water supplies, avoided overgrazing, and also avoided disease-carrying insects in some instances. Hence, stock mobility increased resilience of livestock to adverse climatic conditions reducing the risks of livestock mortality. The survival of livestock had a direct bearing on the sustainability of group ranches because livestock keeping was the main livelihood activity among the group ranchers. Therefore, reduction of livestock losses held the fabrics of group ranches together lowering the rates of group ranch dissolution.

\section{Herd Maximization and Diversification}

Herd maximization strategy entailed keeping as many animals as possible to ensure their survival despite losses incurred during adverse environmental conditions. Given the unpredictable exposure of livestock to harsh environmental conditions, group ranches in the County also adopted diversification of livestock types and breeds. The strategy involved combining different livestock types such as cattle, goats, sheep, 
donkeys, camels, indigenous chicken and commercial chicken under the same management. This provided a wider variety of livestock products. Furthermore, different animal species enabled the ranchers to efficiently use available pasture resources as different species had non-competitive grazing and browsing habits. Different animal types and breeds are affected differently by harsh climates with some being more resilient than others. Rearing different type of stock acted as an insurance against adverse environmental shocks cushioning the ranchers against huge livestock losses.

\section{Herd dispersion}

Interview with the members of group ranches revealed that during adverse environmental conditions, they separated and moved their livestock to areas of different ecological zones. The strategy entailed dividing stock into two or more herding units or splitting whole households between two neighborhoods. It also involved spreading one's livestock to several localities to counteract localized risks of livestock loses due to environmental conditions and also reducing competition among herds for forage and water resources, optimizing pasture use. For instance, members living in the lower parts of Mbaringoni group ranch dispersed their livestock to the upper parts of the group in search of pasture. The strategy was common to many group ranches in the county.

\section{Establishment of feed reserves}

Another strategy adopted by group ranches in Samburu County to counter the effects of environmentally related shocks was the reservation of rich-patch vegetation (feed reserves). During the wet seasons the ranchers set aside grazing areas for use as a "bank" during the droughts or dry seasons. The strategy allowed regeneration of grass and other palatable vegetation suitable for grazing livestock during droughts. For instance, members of Girgir group ranch reserved areas along Ewaso Nyiro River for use during droughts.

\section{Formation of alliances with neighbors}

Interview with the ranchers revealed that during favorable environmental conditions, grazing in the County was confined within the group ranches. However, the ranchers had formed alliances with other ranchers outside their group ranches from whose rangelands, they grazed during droughts after the exhaustion of pasture in their feed reserves. For instances, members of Tinga group ranch had a special arrangement with Suguta Marmur group ranchers. The arrangement was that during droughts, Tinga group ranchers would move their animals to the suguta Marmur whose climatic conditions were more favorable

\section{Conclusion}

The findings provide support for the conceptual framework in Figure 1 regarding the causal relationship between environmental characteistics and choice of sustainability strategies adopted by group ranches. The analytic results demonstrate that rainfall patterns, droughts, diseases, temperatures and floods significantly influenced choice of sustainability strategies adopted by group ranches in Samburu County.

The study concluded that the strategies adopted to cushion group ranchers against adverse environmental conditions were key in holding the group ranches together. The lower risks of losing the livelihood resources led to high chances of having group ranches sustained. The findings of the study revealed that environmental characteristics determined choice of sustainability strategies adopted by group ranches in Samburu County.

The study concludes that due to the rising global demand for livestock products and the increasing degradation of rangelands, where most of the group ranches are established, finding sustainable strategies to meet the global demand for livestock products and conservation of the rangelands is significant.

\section{Acknowledgement}

We are grateful to all individuals and groups of people whose support and encouragement contributed to the finalization of this paper. We are particulartly thankful to Ambassador John L. Lanyanyunya, Kenya 
High Commissioner in Canada, for his financial support that enabled us to travel to Samburu County for data collection.

\section{References}

Borwein, S. (2013).Privatizing pastures: Land Tenure Reform in Kenya's Maasailand and. Public policy and Governance Review, 4(2)

Brown.K. \& Gilfoyle, D. (Eds.). (2009).Healing the Herds: Disease, Livestock Economies, and the Globalization of Veterinary Medicine. Ohio University Press

Calder, R., Zierrogel, G. (2003). Climate Variability and rural livelihoods: assessing the impact of seasonal climate forecasts in Lesotho. Stockholm Environment Institute,Oxford.

Constitution of Kenya (2010), Nairobi. Kenya. Government printers

Deressa T., Hassan, R. and Ringler, C. (2010). Factors Affecting the Choices of Coping strategies for Climate Extremes, IFPRI Discussion Paper 01032, November 2010

FAO (2005). Cattle and Small ruminant production systems in Sub-Saharan Africa: a system review. Food and Agriculture, Rome

Frantin, E. (2008).East African pastoralism in transition: Maasai, Boran, and Rendille cases. African studies Review, 44 (3), 1-25

Gaitho, P. L., (2014). Impact of community based eco-tourism on households' and environmental management in Ilngesi and Lekurruki Group ranches, Laikiia, Kenya. Thesis. Kenyatta University.

Hatfield, R., \& Davies, J. (2006). Global Review of the Economics of pastoralism. IUN, Nairobi.

Hoffman, T. \&Vogel, C., (2008). Climate Change Impacts on African Rangelands.Rangelands, 30(3), 12-17

Huho, J. (2011).Effects of drought severity on subsistence agriculture in the semi-arid Laikipia Distict, Kenya. Thesis.Maseno University.

Huho, J., Ngaira, J., \& Ogindo, H. (2010). Drought severity and their effects on rural livelihoods in Laikipia District, Kenya. J. Geo. RegionaPlanning. 3(3):035-043

Hussey, J. (2010).Ranching into the future. Saving Land Magazine. Arizona

Karodia,M.A. \& Soni, P. (2014).The Land Question in Africa: Reinventing Exploitation, Engendering Displacement and foreboding catastrophe. A discourse journal of Agriculture and Food Science. 2 (11), 295-308.

Kandji, S. T., L. Verchot, and J. Mackensen. 2006. Climate change and variability in the Sahel region: impacts and adaptation strategies in the agricultural sector. United Nations Environment Programme (UNEP) and World Agroforestry Centre (ICRAF), Nairobi, Kenya.

Kibugi, M. (2009). A failed land use legal and policy framework for the African Commons: Reviewing rangeland governance in Kenya. Paper presented at university of Ottawa.

Kipainoi, M. (2013). Diversification of livelihood strategies among Maasai of lolgorien ward, Narok County, Kenya. Master Thesis. Kenyatta University.

Kothari, C.R. (2004). Research Methodology, Methods and Techniques ( $2^{\text {nd }}$ Edition). New Delhi: New Age international publishers.

Lengoiboni, M. (2011). Pastoralists Seasonal land rights in land administration. A study of Northern Kenya. Enscheles, Netherlands.

Lesorogol, C.K (2008). Land privatization and pastoralist in Kenya. Development and change, 39 (2), 309331

Masharen, S. (2015). Drought Scare in Maasai land, Kenya http://loitokitok.com

Mule, J. (2010).Socio-economic Impacts of land sub-division in Kenya's dry lands: a case study of Kimana/Tikodo group. Thesis. University of Nairobi.

Mwakima,M.W.(2013). Determination of the Bio-diversity conservation-Tourism Nexus in the Buffer Zone of Amboseli Biosphere Reserve, Kenya. Thesis. Kenyatta University.

Mwangi, E. (2007a). 'Subdividing the Commons: Distributional Conflict in the Transition from Collective to Individual Property Rights in Kenya's Maasailand', World Development. 35(5), 815-34.

Mwangi, E. (2007b). 'The Puzzle of Group Ranch Subdivision in Kenya's Maasailand', Development and Change. 38(5), 889-910.

National Land Commission Strategic Plan, 2013-2018.Nairobi 
Ng'ang'a, S.L., Koskei Z. K. \& Gathuthi, E.W. (2009). Fundamentals of Management Research Methods. Nairobi: Macmillan Kenya Publishers.

Noor et al (2013).Assessment of camel and camel milk marketing practices in emerging peri-urban production system in Isiolo County, Kenya. Pastoralism: research, policy and practice, 3(28).

Nooraie, M.(2011). Decision's familiarity and strategic decision-making process output: the mediating impact of rationality of the decision-making process. International Journal of Applied Decision Sciences (IJADS) 4, 385-400

Ntiati, P. (2002).Group Ranches Subdivision Study in Loitokitok Division of Kajiado District, Kenya. The Land Use Change, Impacts and Dynamics Project Working Paper, 7, 1-25.

Odari, S. (2010).Factors influencing commercial ranching in Kinango District.Thesis.UON

UNEP (2015). Sustainable Pastoralism and Post 2015 agenda.

USAID. (2011). Land Tenure and property rights. Programme brief.

Veit, P. (2011).Rise and fall of group ranches in Kenya. Focus on land in Africa.

Wachira, M. (2008).Vindicating Indigenous Peoples' Land Rights in Kenya. Faculty of Law, University Of Pretoria

Wayumba, O.G.(2013).An evaluation of the cadastral system in Kenya and a strategy for its modernization. Thesis. University of Nairobi. 